\title{
What the women of Dublin did with John Locke
}

\section{Christine Gerrard, Lady Margaret Hall, Oxford}

One of the most endearing traces of Locke's influence on Dublin women writers can be seen in a small poem published in 1735, 'Written for My Son, and spoken by him in School, upon his Master's first bringing in a Rod'. ${ }^{1}$ The schoolboy speaking the poem complains bitterly about the grim prospect of school beatings, then turns to praise 'that great Sage', who 'Who taught to play us into Learning, / By graving Letters on the Dice'. The 'Sage' is John Locke, who in his 1693 Thoughts Concerning Education recommends that children should enjoy learning their alphabet by playing with a polygon with letters engraved on each face. The child ends by showering praise on Locke:

May Heav'n reward the kind Device.

And crown him with immortal Fame,

Who taught at once to read and game!

O may I live to hail the Day,

When Boys shall go to School to play!

To Grammar Rules we'll bid Defiance

For Play will then become a Science.

The poem's author is Mary Barber (1685-1755). Her son Constantine, or 'Con', for whom she wrote the poem, grew up to become President of the College of Physicians in Trinity College Dublin. Its blend of humour, domesticity, and light-hearted engagement with education and philosophy is characteristic of the writings of a group of Dublin women to which Barber belonged, often known as Swift's 'Triumfeminate' through their associations with their more famous mentor Jonathan Swift. The group comprised, at various points, Barber (also known as the 'Citizen's Housewife poet' because of her humble origins as a draper's wife), the poet and scandal memoirist Laetitia Pilkington, daughter of a Dublin

\footnotetext{
${ }^{1}$ Mary Barber, 'Written for my Son, and spoken by him in School, upon his Master's first bringing in a Rod', Poems on Several Occasions (London, 1734) [1735], pp. 36-7.
} 
doctor and obstetrician, the classicist, poet and printer Constantia Grierson, and Elizabeth Sican, also married to a printer. ${ }^{2}$ To identify these women merely as Swift's protégés (or, as Swift's friend Orrery suggested, his 'Seraglio') is of course reductive. Though Swift undoubtedly helped promote Barber's and Pilkington's careers, there were other intellectual and literary influences at work. ${ }^{3}$ The cultural background these women shared reveals a more complex engagement with philosophical ideas current in Dublin at the time, gleaned through their connections with brothers, husbands and fathers at Trinity College Dublin, as well as the literary gatherings held by Patrick Delany on Thursday afternoons, nicknamed the 'Dublin Thursday Society', at his suburban Dublin villa, Delville, at Glasnevin. ${ }^{4}$

Recent scholarship has paid considerable attention to Locke's 'feminisms', particularly Locke's critique of Robert Filmer's patriarchalism and the extent to which his contract theory includes or excludes women. ${ }^{5}$ Yet most studies of Locke's influence on contemporary women writers have been confined to his associations with the feminist Mary Astell, his close friendship and correspondence with Damaris Cudworth, and his admiration for Catharine Trotter Cockburn, whose high-minded 1702 defence of Locke's Essay Concerning Human Understanding, aligning Locke's moral philosophy with Christian theology, represents one end of a spectrum of women's responses to Locke's thought. ${ }^{6}$ At the other end of the spectrum we find female readers and enthusiasts for Locke whose engagement with him was of a more mediated, domestic kind. Of this kind were the women of the Dublin circle, whose exposure to Locke came through daily domestic contact,

\footnotetext{
${ }^{2}$ For recent work on this circle, see Louise Barnett, Jonathan Swift in the Company of Women (Oxford: Oxford University Press, 2006), pp. 73-97; Christine Gerrard, 'Senate or Seraglio: Swift's “Triumfeminate" and the Literary Coterie', Eighteenth-Century Ireland 31 (2016), pp. 13-28, and Catherine Ingrassia, 'Elizabeth Thomas, Laetitia Pilkington, and Competing Currencies of the Book', Women's Writing 23 (2016), pp. 312-24.

${ }^{3}$ For a reading of the circle outside Swift's influence, see Paula Backscheider, 'Inverting the Image of Swift's "Triumfeminate"', Journal for Early Modern Cultural Studies 4: 1 (2004), pp. 37-71. Mary Barber's friendship with the Bluestocking Mary Pendarves, who married Patrick Delany in 1743, predated her friendship with Swift by at least 13 years.

${ }^{4}$ See Gerardine Meaney, Mary O'Dowd and Bernadette Whelan, Reading the Irish Woman: Studies in Cultural Encounters and Exchange, 1714-1960 (Liverpool: Liverpool University Press, 2013), pp. 19-20, 24-5; A. C. Elias Jr (ed.), The Memoirs of Laetitia Pilkington (2 vols., Athens, Ga: University of Georgia Press, 1997), vol. 1, pp. 283, 387, vol. 2, p. 674 n. 283:13.

${ }^{5}$ For a range of feminist readings, especially of the Two Treatises, see especially Nancy J. Hirschman and Kirstie M. McClure, eds., Feminist Interpretations of John Locke (University Park, Penn: Penn State University Press, 2007).

${ }^{6}$ Catharine Trotter Cockburn, A Defence of Mr. Lock's Essay Concerning Human Understanding (London, 1702). See especially Kathryn Ready, 'Damaris Cudworth Masham, Catharine Trotter Cockburn, and the Feminist Legacy of Locke's Theory of Personal Identity', Eighteenth-Century Studies 35:4 (2002), pp. 565-576; Patricia Sheridan, 'Reflection, Nature and Moral Law: The Extent of Catharine Cockburn's Lockeanism in her Defence of Mr. Locke's Essay; S. Parague, "'A Defence of the Essay on Human Understanding (1702) by Catharine Trotter: Or, How Lockean Theory of Personal Identity suits Women', Dix-Huitieme Siecle 275, 353-369.
} 
conversations and book borrowing from fathers, brothers and sons who studied or taught at Trinity College Dublin, where Locke had been on the curriculum since 1692 . One of the ways in which Locke was disseminated among a wider range of women readers was via popular miscellanies on philosophy and education aimed at women readers. The young George Berkeley, future Bishop of Cloyne, compiled in 1714 The Ladies Library, which included excerpts from Locke, Astell and Fenelon, among others, for the purposes of educating female readers. ${ }^{7}$ This domestic, or 'second-hand' exposure to intellectual ideas in an age when most women were denied access to formal education and certainly to the study of philosophy, is a process worth studying as evidence of female acculturation to complex philosophical ideas. The women of the Triumfeminate redeployed Locke through a distinctively female, sometimes feminist lens, whilst also engaging thoughtfully - yet also playfully - with some of the larger questions of understanding, education and memory raised by texts such as the Essay Concerning Human Understanding and Some Thoughts Concerning Education. ${ }^{8}$

Cultural historians have shown the long reach which Locke's writings had on early eighteenth-century Ireland. ${ }^{9}$ Locke's association with Ireland began properly through his friendship with Sir William Molyneux, founder of the Dublin Philosophical Society and the first translator into English of Descartes' Meditations, although Locke had also previously known William's younger brother Thomas when both were studying medicine in Leiden. William's praise of Locke in the dedication of his Dioptrica Nova (1692) sparked an intimate, intellectual and personal correspondence that ended only when Molyneux died in 1698. It was Locke's closeness to Molyneux, whose wife Lucy Domville tragically went irreversibly blind in the year of their marriage, that led him to include a discussion of the socalled 'Molyneux's problem' in his Essay - whether a man born blind but restored to sight could visually distinguish between shapes such a cube and a sphere which he had previously known only by touch. ${ }^{10}$ The publication in 1708 of Molyneux's Some Familiar Letters

\footnotetext{
${ }^{7}$ Meaney, Reading the Irish Woman, p. 17. Although no Irish edition of this text has yet been found, Berkeley's compilation of educational texts printed both in Dublin as well as London indicates the free flow of ideas about education between London and Dublin

${ }^{8}$ The idea of 'play' within the reception of philosophical ideas might be fruitfully explored further in relation to this circle. Molyneux memorably used the word 'jocose' to describe his famous 'Molyneux's problem'. See William Molyneux et al., Some Familiar Letters between Mr. Locke, and Several of his Friends (London, 1708), pp. 37-8.

${ }^{9}$ See especially Patrick Kelly, 'Perceptions of Locke in Eighteenth-Century Ireland', Proceedings of the Royal Irish Academy: Archaeology, Culture, History, Literature, 89 (1989), pp. 17-35.

${ }^{10}$ See Some Familiar Letters, pp. 37-8.
} 
between Mr Locke, and Several of his Friends, was key to getting Locke known in Dublin, and a source of local pride. The Familiar Letters were primarily concerned with the education of Molyneux's son Samuel, but also contained extensive correspondence between Locke and Molyneux over the manuscript of what was published as Some Thoughts concerning Education, particularly Molyneux's very liberal responses to some of Locke's strictures on child discipline. 'Such a work as this I desire', wrote Molyneux, 'and that too, at the request of a tender father, for the use of his only son'. ${ }^{11}$ Some Thoughts Concerning Education, published in London in 1693, was first published in Dublin in 1728, and there were five Irish reprints of the text (2 editions in 1728), 1737, 1738 and 1778. As Gerardine Meaney has shown, Berkeley used extensive passages from the text, alongside excerpts from Astell and Fenelon, for his 1714 anthology and educational guide, The Ladies Library. ${ }^{12}$ Locke's engaging, modern treatise on child rearing, adopting a rational, humane, common sense approach to motherhood and infancy, proved one of the most popular guides in England for parents and tutors on how to educate children in an enlightened fashion. It proved no less popular in Dublin, where it was aimed at the children of the gentry, part of Berkeley's project to develop an educated gentry class, but was also disseminated down to the middle and trading classes.

Locke's privileged position in Dublin intellectual circles also stemmed from the early inclusion on the Trinity College curriculum of his Essay Concerning Human Understanding which became a set text in 1692 after William Molyneux recommended it to the provost, St George Ashe. Locke as a political thinker and writer on economics was less widely known in Ireland. Although Jonathan Swift owned copies of, and drew on Locke's treatises on money in his Drapier's Letters (1724), and Molyneux drew on Locke's Two Treatises for his inflammatory 1698 The Case of Ireland, it was not until 1798 that the Two Treatises were added to the Trinity College Dublin university curriculum. ${ }^{13}$

Thus early eighteenth-century Dublin knew Locke not primarily as a political or economic writer, but as a philosopher interested in the development of human perception and understanding, and perhaps even more importantly, as an educational writer, with an interest in childhood development and how children learn, and also in parent/child relationships, maternity and childbirth. Insightful recent scholarship has shown how Locke's experience as

\footnotetext{
${ }^{11}$ Some Familiar Letters, p. 35.

12 Meaney, Reading the Irish Woman, p. 17.

${ }^{13}$ See Kelly, 'Perceptions of Locke in Eighteenth-Century Ireland', pp. 20-24.
} 
medical practitioner intersects with and shapes his role on writing for and about women. As Joanne Wright has shown, during his period of political exile in the Netherlands between 1683-8, Locke was part of a close-knot circle of Dutch medical scholars and practitioners, with a particular interest in male midwifery. It was in Leiden that some of Locke's early connections with Dublin were formed, such as with Thomas Molyneux, William's younger brother, who was studying medicine there. Leiden was a hub for European medical training. ${ }^{14}$ John Van Lewen, Laetitia Pilkington's father, also studied medicine at Leiden and worked with Boerhaave (he was there slightly after Locke but almost certainly became familiar with his work at this time. ${ }^{15}$ The Molyneux family had close links with the Van Lewen family in Dublin: Thomas Molyneux was a colleague of John Van Lewen at the College of Physicians. Thomas's son Daniel Molyneux was very close friends with Laetitia's younger brother Meade.

Like Locke, Van Lewen was very interested in obstetric practice, and when he returned to Dublin from Leiden, 'there then being but one Man-Midwife in the Kingdom; my Father made himself Master of that useful Art, and practis'd it with great Success, Reputation, and Humanity'. It was this reputation as a male midwife that first attracted the bookish and precociously scholarly Constantia Crawley to the Van Lewen household, where she lodged in order to study professional midwifery under Van Lewen. The Dublin Scussles, or the hungry poets petition praises one 'Miss Crawley, a lady of notable abilities... no less famous for her Poetical Prowess than her skill in Midwifery'. Born in Kilkenny to humble parents, Constantia Crawley, later Grierson, was a child prodigy who mastered Latin, Greek and Hebrew and French, much of it self-taught. She married the printer George Grierson and shared the honour of being King's Printer, acting as editor and compositor for many of the works his press published. She died aged 27 after acquiring a formidable reputation as editor and classical scholar. Constantia and Laetitia, who lived in the same house for a period of time, became very close friends, sharing an interest in philosophical and scientific ideas, as well as affectionate youthful exchanges of poems. ${ }^{16}$

\footnotetext{
${ }^{14}$ See Pilkington, Memoirs, 2, pp. 369-70, n. 12:40.

${ }^{15}$ See Joanne H. Wright, 'Recovering Locke's Midwifery Notes', in Hirschbaum and McClure, eds., Feminist Interpretations of John Locke, 213-240. She notes that Locke's writings on midwifery reveal his most engaged thoughts about the role of the maternal, the importance of the mother upon early childhood development, and the rational role of education

${ }^{16}$ See 'To Mrs Van Lewen at a Country Assize', and 'To the Same on the Same Occasion', in Pilkington, Memoirs, I, pp. 18-20.
} 
Laetitia Pilkington and Constantia Grierson both became friends with the significantly older Mary Barber, who by the early 1720s had started to become well known in Dublin. Barber, a highly intelligent, independent-minded woman, who struggled to overcome adversity (marriage to a failing linen draper, four dependent children and poor health), had been friends with Patrick Delany since 1719, long before her association with Swift. She was also close friends with the independent-minded widow Mary Pendarves, her great supporter, who married Delany in 1743. Barber's son Rupert, who became a famed portrait painter, married Delany's niece. They were all part of the group that met regularly, along with Matthew Pilkington, Swift and the Carterets, at Delville, where they discussed philosophical and literary topics. Barber showed a keen interest in Locke's work, and makes explicit, often playful reference, to his ideas, especially on education, child rearing, and man in a state of nature. Barber's Poems on Several Occasions of 1734 (in fact published in 1735), aided by Swift's support, attracted a huge subscription list of over 900 subscribers including peers and distinguished literati in both Ireland and England. ${ }^{17}$ Her relationship with her four surviving children, particularly her two older sons, Constantine and Rupert, was often the stimulus for and the very subject of her poems. At least fifteen of her poems are explicitly written for her children, and the role of the maternal in education, as well as within marriage, reflects a reading probably not just of Locke but also of Mary Astell, whose Some Reflections Upon Marriage may have been introduced to her by Mary Pendarves. ${ }^{18}$

Despite his commitment to a paternalistic family order, Locke considered the mother equally capable of raising children as the husband. In the wilder worlds imagined by the Two Treatises, Locke notes that 'In those parts of America where when the Husband and the Wife part, which happens frequently, the Children are all left to the Mother, follow her, and are wholly under her care and Provision'. ${ }^{19}$ In Thoughts on Education he advocates that all

\footnotetext{
${ }^{17}$ See Emily O'Flaherty, 'Patrons, Peers and Subscribers: The Publication of Mary Barber's Poems on Several Occasions (1734), PhD. thesis, NUI Galway, 2013.

${ }^{18}$ There is no conclusive evidence that Barber and her circle were familiar with Locke's Two Treatises, with their attacks on Filmerian patriarchy, but they were certainly familiar with Mary Astell, whose Some Reflections on Marriage was reprinted in a Dublin edition in 1730 and suggests an interest by the Dublin literati in the circle around Mary Delany in her radical views on the status of women in society. Astell criticised women's entrapment in forced marriages and decried misogyny; 'if a man could respect his own wife when he has a contemptible opinion of her and her sex? When from his own elevation he looked down on them as void of understanding, full of ignorance and passion, so that folly and a woman are equivalent terms with him'. 'A Conclusion of a Letter to the the Reverend $\mathrm{MrC}$ ' Barber draws on both Astell and possibly Locke (who challenged Filmer's presumptions of familial authority based on patriarchal rule and the implicit subjection of women). The Irish vicar vilifies a rational, intelligent and educated wife like Mrs Barber, seeking instead a domestic slave who will 'serve and obey, as she's bound by her Vows'.

${ }^{19}$ Locke, A Second Treatise on Civil Government (1690), chapter VI, 'Of Paternal Power'.
} 
children should be initially be educated at home, rather than at school - a mode customary to the education of girls, rather than boys. In his version of home schooling, he sees mothers as essential. He praises the role of mother as early educator: 'and indeed whatever stir there is made about getting of Latin, as the great and difficult business, his Mother may teach him herself, if she will but spend two or three hours a day with him'. ${ }^{20}$ Locke's strong belief in the power of mothers as early educators might have found an embodiment in Mary Barber, who invested an extraordinary level of effort and responsibility - as well as genuine pleasure - in her children's education. In her Preface to her Poems Barber claims that the education of her children was her chief reason for writing and publishing verse: she wrote her poems 'To form the Minds of my children' as 'I imagined that Precepts conveyed by verse would be easier remembered': 'What has the public to do with verses written between a mother and her son? I answer, that as nothing can be of more use to society than the taking every care to form the minds of youth, I publish some of the verses written by me with that view, when my son was a schoolboy, as the best apology a woman could make for writing at all. ${ }^{21}$ Barber's interest in education went far beyond the modest female defence of writing for one's family that women writers were forced to adopt to sanction and legitimise their appearance in print. Many of her poems embody the 'rational enlightenment' approach to learning, inculcated by maternal instruction. The pleasure that Barber took in this role is evident from one of the early poems in Poems on Several Occasions, 'A True Tale', which depicts her at home with her children:
A mother, who vast Pleasure finds
In modelling her Childrens Minds;
With whom, in exquisite Delight,
She passes many a Winter Night;
Mingles in ev'ry Play, to find
What Byass Nature gave the Mind.22

Barber's role as a closely involved maternal educator of her own children, especially her sons, is remarkable for its time, and show the influence which Locke's ideas on education had on Irish readers. In her 'Conclusion of a Letter to the Reverend Mr C', a poem in which

\footnotetext{
20 John Locke, Some Thoughts Concerning Education (London, 1693), p.

${ }^{21}$ Barber, Poems, xvii-xviii.

22 Barber, Poems, p. 7.
} 
she mimics a misogynistic Irish cleric who wants to marry an uneducated wife he can master and dominate, she passes down this advice to her son when he comes to have children of his own: his wife should be both an intellectual companion and educator of their children.

Yet still, let her principal Care be her Mind:

In forming her Children to Virtue and Knowledge,

Nor trust, for that Care, to a School, or a College. ${ }^{23}$

Barber had clearly assimilated Locke's Thoughts on Education closely. Although the earliest Irish edition of 1728 was aimed at an elite -- 'Published at the request of several of the nobility of the kingdom' - in line with Berkeley's ideal of an educated, responsible and paternalistic Irish gentry who would provide a lead in the improvement of their localities, Locke's text had a far broader social appeal. The Dublin subscription list included many ordinary local tradespeople. Exerts from it were printed in the 1735 Dublin reprint of The Apprentices' Vade Mecum, whose author, Samuel Richardson, drew heavily on Thoughts on Education in his second 'Pamela' novel, Pamela in Her Exalted Condition (1642), devoted to the servant Pamela's rearing and education of her children with the aristocrat $\mathrm{Mr} \mathrm{B} .{ }^{24}$ Samuel Richardson, a friend of Mary Barber and publisher of her Poems on Several Occasions, would undoubtedly have approved of her educational aims and poems drawing on Locke's theories on education, designed to improve the minds of her children.

Barber uses her closeness to her oldest son Con to comment on his daily life at school, his relationship with his school friends, and especially his school masters. She ventriloquizes Con's voice to explore and critique contemporary educational practices and other social ills from a child's viewpoint. The poem with which I opened, 'Written for My Son, and spoken by him in School, upon his Master's first bringing in a Road', echoes one of Locke's abiding concerns in education, the role which corporal punishment should, or ideally should not, play at home and in school. Locke himself was severely beaten at Westminster school under the notorious Dr Busby, and in the preface to Thoughts on Education he suggests that his friend Edward Clarke might send his own recalcitrant son there for a short period of time to instil in him gratitude for the more benevolent regime of home schooling. Thoughts on Education is regularly punctuated by Locke's protests against the inefficacy and cruelty of beating, for example, 'Beating then, and all other Sorts of slavish and corporal Punishments, are not the

\footnotetext{
${ }^{23}$ Barber, Poems, p. 61.

${ }^{24}$ Samuel Richardson, Pamela in Her Exalted Condition, ed. Albert J. Rivero, Cambridge: Cambridge University Press, 2012.
} 
Discipline fit to be used in the Education of those who would have wise, good, and ingenuous Men'. ${ }^{25}$ Locke believed that persuasion and argument were far more effective than the rod in teaching a child. In the Familiar Letters Molyneux discussed Locke's fondness what we would now describe as 'educational toys', 'the contrivances you propose for teaching them to read and write' including games to teach the alphabet and writing skills. ${ }^{26} \mathrm{In}$ 'Upon his Master's first bringing in a Rod', Con echoes Locke's opinion that education should involve fun and play, rather than whipping and beating.

That Sage* was surely more discerning

Who taught to play us into Learning,

By graving Letters on the Dice:

May Heav'n reward the kind Device.

And crown him with immortal Fame,

Who taught at once to read and game! ${ }^{27}$

The asterisk is footnoted with a reference to 'Mr Locke', who advocates that 'Play will then become a Science.' The reference to 'graving Letters on a Dice' refers to section 149-50 of Thoughts on Education:

Thus Children may be .... taught to read, without perceiving it to be any thing but a Sport, and play themselves into that which others are whipp'd for . . . I have therefore thought, that if Play-things were fitted to this purpose, Contrivances might be made to teach Children to Read, whilst they thought they were only playing. For example, What if an Ivory Ball were made like that of the Royal-Oak lottery, with Thirty two sides, or one rather of Twenty four or Twenty five sides; and upon several of those sides pasted on an A, upon several others B, on others C, and on others D? I would have you begin with but these four Letters, or perhaps only two at first; and when he is perfect in them, then add another; and so on till each side having one letter, there be on it the whole Alphabet. ${ }^{28}$

\footnotetext{
${ }^{25}$ Locke, Thoughts on Education, p. 50-51.

${ }^{26}$ Familiar Letters, p. 53.

${ }^{27}$ Barber, Poems, pp. 16-17.

${ }^{28}$ Thoughts on Education, pp. 178-9.
} 
Locke's Thoughts on Education also inspired Barber's most frequently anthologised poem, 'Written for my Son, and spoken by him at his first putting on Breeches'. In this imaginative, delightful poem, Barber adopts the voice of a much younger Con, around the age of seven or eight, complaining about being 'breeched' - the transition from wearing infantile gender-neutral frocks into formal clothes. ${ }^{29}$ He protests against the ill effects of being made to wear stiff, formal and tight-fitting clothing.

WHAT is it our Mamma's bewitches,

To plague us little Boys with Breeches?

To tyrant Custom we must yield,

Whilst vanquish'd Reason flies the Field. ${ }^{30}$

Christopher Fanning has quite persuasively interpreted this poem as a deliberate act of gender switching in which Barber covertly uses her young son to ventriloquize female grievances against patriarchal oppression. ${ }^{31}$ The small boy rehearses complaints more often made by women, he argues, about the tyranny of custom and appearance, and the need to be 'tightlaced' to attract potential suitors and to meet society's demands. Yet it is clear to anyone who has read Thoughts on Education that Barber is echoing Locke's radical hostility to oppressive forms of 'Custom' in dress which damage and constrain the 'natural' development of the human body. Man in a 'state of nature' is far better than man tricked out in artificial fashions dictated by the tyrant Custom.

Barber's foot obsession - she suffered chronic, debilitating bouts of gout - is also shared by Locke, who saw bare feet as the very foundation for good health. In Thoughts on Education he recommends that children should walk barefoot in the cold and wet to make them hardier (the idea derives from Montaigne but Barber must have thought of Irish peasant children, often walking barefoot in the cold). 'I should advise his Feet to be washed every

\footnotetext{
${ }^{29}$ See Chantal Lavoie, 'Tristram Shandy, boyhood, and breeching', Eighteenth-Century Fiction, 28: 1 (2015), pp. 85-107.

${ }^{30}$ Barber, Poems, p. 13.

${ }^{31}$ Christopher Fanning, 'The Voices of the Dependent Poet: The Case of Mary Barber', Women's Writing 8 (2001), pp. 81- 98.
} 
night in cold water'. This is part of Locke's ongoing debate with the natural as opposed to the over-refined and over-bred. ${ }^{32}$

Those who have been bred nicely, will wish he had, with the poor people's children, gone bare-foot; who, by that means, come to be so reconciled by custom, to wet their feet, that they take no more cold or harm by it, than if they were wet in their hands. And what is it, I pray, that makes this great difference between the hands and the feet in others, but only custom? I doubt not, but if a man from his cradle had been always used to go bare-foot, whilst his hands were constantly wrapped up in warm mittens, and covered with Handshooes, as the Dutch call gloves; I doubt not, I say, but such a Custom would make taking Wet in his Hands, as dangerous to him, as now taking Wet in their Feet is to a great many others. ${ }^{33}$

Barber's son complains about tight shoes and their damaging effects:

Our Legs must suffer by Ligation,

To keep the Blood from Circulation;

And then our Feet, tho' young and tender,

We to the Shoemaker surrender;

Who often makes our Shoes so strait,

Our growing Feet they cramp and fret;

Whilst, with Contrivance most profound,

Across our Insteps we are bound;

Which is the Cause, I make no Doubt,

Why Thousands suffer in the Gout. ${ }^{34}$

This mirrors Locke's passage on Chinese female foot-binding in Thoughts on Education: 'These Defects in the Female Sex in that Country, are by some, imputed to the unreasonable binding of their Feet; whereby the free Circulation of the Blood is hindred, and the Growth

32 See Robert Mankin, 'Locke's Education of the Personality', Études Anglaises 58: 4 (2005), pp. 387-401. 33 Thoughts on Education, pp. 5-6.

${ }^{34}$ Barber, Poems, p. 13. 
and Health of the whole Body suffers. And how often do we see, that some small part of the Foot being injured by a Wrench or a Blow, the whole Leg and thigh thereby lose their Strength and Nourishment, and dwindle away? ${ }^{35}$

For Barber, as for Locke, shoes are just the start of the problem. Locke bases his philosophy on the idea that man was born with a natural right of freedom, and in Thoughts on Education he applied his ideas from the moment of birth, condemning the widespread practice of swaddling children and robbing them of physical freedom: 'The poor Thing lies on the Nurse's Lap, a miserable little pinioned Captive, goggling and staring with its Eyes, the only organ it has at Liberty, as if supplicating for Freedom to its Fetter'd Limbs'. This practice is reintroduced in later childhood. Locke advises that

your Son's Cloths be never made strait, especially about the Breast. Let Nature have scope to fashion the Body as she thinks best: she works of herself a great deal better, and exacter, than we can direct her ... Narrow Breasts, short and stinking Breath, ill Lungs, and Crookedness, are the Natural and almost constant Effects of hard Bodice, and Cloths that pinch. That way of making slender waists, and fine shapes, serves but the more effectually to spoil them. Nor can there, indeed, but be disproportion in the parts, when the nourishment, prepared in the several offices of the body, cannot be distributed, as nature designs. ${ }^{36}$

Barber ends with her poem roundly rejecting the tyrant 'Custom' in favour of 'Natural Man' and 'Natural Reason'. The animals and birds all dress in perfect proportion to their wants and needs, so why can't we?

O'er human Race the Tyrant reigns, And binds them in eternal Chains.

We yield to his despotic Sway,

The only Monarch All obey. ${ }^{37}$

\footnotetext{
35 Thoughts on Education, p. 12.

${ }^{36}$ Thoughts on Education, pp. 10-11.

${ }^{37}$ Barber, Poems, p. 16.
} 
The Memoirs of Laetitia Pilkington, published between 1748 and 1754 by Mary Barber's Dublin friend, and later rival, Laetitia Pilkington, also testify to a domestic familiarity with Locke. Recent scholarly attention to Pilkington has focused more on her autobiographical survival strategies for surmounting a series of abusive relationships with more powerful men (Swift has been included in this category) than on her intellectual seriousness and engagement with philosophical or scientific debate. Yet it is often forgotten that Pilkington, before she acquired a reputation as a Grub street demimondaine, was better known as the youngest daughter of a distinguished doctor, John Van Lewen, President of the College of Physicians, and that her mother Elizabeth was an educated and intellectual woman, who also attended the Thursday salon gatherings at Patrick Delany's Delville. Pilkington obviously did not enjoy the benefits of the Trinity College education experienced by her younger brother Meade, but she grew up in a house surrounded by books, ideas and conversation. The intellectual Mary Pendarves described a Sunday evening visit in December 1731،

Spent the evening at Doctor Van Luens. I believe I have mentioned that family to you before: they are sensible and cheerfull. It was proposed by Mrs Van Luen that everybody should own what quality they valued themslevs most for, and afterwards, what they most disliked in themselves: this fancy made us very merry, and made our conversation not unlike some in Clelia [de Scudery’s philosophical novel, 1644-1661]. ${ }^{38}$

Laetitia was also, as Catherine Ingrassia has shown, a voracious reader in Swift's library, and her love of reading, writing and memorising texts started in infancy. ${ }^{39}$ She also had a serious interest in scientific ideas, striking up a friendship in London with the eminent physiologist Stephen Hales in 1739 (Memoirs,1. 33-4). She was clearly familiar, as we will see, with both Thoughts on Education and The Essay on Human Understanding. Patrick Kelly notes that undergraduate understanding of the nuances of Locke's Essay, part of the curriculum since 1692, were often shaky. More than a century later, the eminent Dublin lawyer Sir Jonah Barrington commented that 'the college course at that time, though a very learned one, was ill-arranged, pedantic, and totally out of sequence. Students were examined in Locke on the

\footnotetext{
${ }^{38}$ A. C. Elias Jr (ed.), The Memoirs of Laetitia Pilkington (2 vols., Athens, Ga: University of Georgia Press, 1997), vol. 2, p. 374, n. 16:23. All further references to the Memoirs are taken from this text. 39 Ingrassia, 'Elizabeth Thomas, Laetitia Pilkington, and Competing Currencies of the Book'.
} 
Human Understanding, before their own had arrived at the first stage of maturity'. ${ }^{40}$ Arguably a clever, quick and curious young woman like Pilkington, raised in an intellectual Dublin household, might have come to a better understanding of Locke's ideas than many male undergraduates. Pilkington clearly enjoyed playing word games at home which depended on puns and ambiguity. Snippets from diaries and letters of Trinity College students during this period show a familiarity with Locke that anticipates the playful pleasure in the ambiguity of words that we find in the work of another Irish writer, Laurence Sterne. In his autobiographical novel The Life of John Buncle (1753), the former Trinity College student Thomas Amory praises his first year encounter with Locke's Essay very highly: 'When I was sent to University .... The first book I took in my hand was the Essay of that fine Genius $\mathrm{Mr}$ Locke ... who shewed me greatly how true knowledge depended on a right meaning of words. ${ }^{41}$ In her Memoirs, Pilkington engages repeatedly with Locke's Essay. She recalls a Lockian conversation with her younger brother Meade over the 'right meaning of words'. Meade 'teiz'd me one Evening to write some verses as a School Exercise for him'. 'I asked him what I should write upon'. 'What should you write Upon', he replies, 'but the Paper?' (Memoirs, 1. 45). The ambiguity of the preposition 'Upon' recalls Locke's discussion of 'the doubtfulness or ambiguity of the signification of words'. Pilkington responds to Meade's teasing with a poem, 'O spotless Paper, fair and white', later given the title 'Carte Blanche', which she prints in the Memoirs. In his Some Thoughts on Education Locke describes the child's mind as 'White Paper, or Wax, to be moulded and fashioned as one pleases'. In her impromptu poem occasioned by her brother's teasing, Pilkington's blank sheet of paper becomes a metaphor for that schoolboy's mind. As Chantel Lavoie notes of this poem, the title 'Carte Blanche' 'may refer not only to the purity of the unspoiled page, but also to the possibilities presented by John Locke on the changeable nature of humanity, and the personality as a tabula rasa. ${ }^{42}$

It is through the lens of Locke's Essay that Pilkington filters her personal memories of her childhood experiences of education and learning. Her rather bitter recollection of her mother's daily beatings owes far less to Locke's benign Thoughts on Education, with its general hostility to corporal punishment of children, than to the Essay on Human

\footnotetext{
${ }^{40}$ Kelly, 'Perceptions of Locke', p. 22.

41 [Thomas Amory], The Life of John Buncle, Esq. (London, 1753), p. 6.

${ }^{42}$ Chantel M. Lavoie, 'Poems by Eminent Ladies: A Study of an Eighteenth-Century Anthology', doctoral thesis, University of Toronto, 1999, p. 208.
} 
Understanding's account of childhood memory retention through pain and pleasure.

Pilkington's mother clearly did not follow Locke's injunctions against corporal punishment. 'My mother strictly followed Solomon's Advice, in never sparing the Rod ... whether I deserv'd it or not, I was sure of Correction every Day of my Life' (Memoirs, 1. 13). Pilkington relates how her mother prevented her from trying to read books, following a bout of smallpox which had weakened her sight and which threatened her looks and hence marriageability. When she pestered her exasperated mother for the meaning of a word, she 'would tell me the Word, but accompany it with a good Box on the Ear, which I suppose, imprinted it on my Mind'. Her phrase 'imprinted it on my Mind' recalls Locke's terminology in his tabula rasa discussion in Some Thoughts on Education, showing how ideas are imprinted on the childhood mind through sensory impressions. Pilkington claims that her mother's ear-boxing 'had this Effect on me, insomuch that I never forgot what was ever told me; and quickly arrived at my desir'd Happiness, being able to read before she thought I knew all my Letters'. The enforcement of memory through pain echoes Locke's Essay Concerning Human Understanding: 'Attention, repetition, pleasure and pain, fix ideas. Attention and repetition help much to the fixing any ideas in the memory. But those, which naturally at first make the deepest and most lasting impressions, are those that are accompanied with pleasure or pain ... pain should accompany the reception of several ideas'. ${ }^{43}$ Pilkington ironically equates pain with rapid acquisition of literacy but is very clear that this is not the best way to learn. In her Memoirs she contrasts this severe and painful mnemonic tool with the more positive rewards - high praise, commendation, and a shilling that her father gives her for learning to read.

Pilkington was clearly particularly interested in Locke's theories of memory in the Essay's Chapter X 'Of Retention'. This is an unusual and early female interest in memory and cognition. Women writers had long been associated with memory, but more often memory as a pious, social and commemorative act - the recording of the passing of life, expressed in the elegy for the dead parent, spouse and most commonly child. ${ }^{44}$ Memory as a cognitive function, or as something which related to a sense of individual personal identity and development, did not emerge until far later. Yet in the Memoirs, which spend so much time

\footnotetext{
${ }^{43}$ John Locke, An Essay Concerning Human Understanding, ed. Roger Woolhouse (London, 1997), p. 148.

${ }^{44}$ See esp. Anne K. Mellor, '"Anguish no Cessation Knows": Elegy and the British Woman Poet, 1660-1834', in Karen Weisman (ed.), The Oxford Handbook of the Elegy (Oxford, 2010), pp. 442-62, and Christine Gerrard, 'Memory and the Eighteenth-Century Female Poet', in Memory in Western Literature, 3 vols. (Sivas, Turkey, 2018), vol. 1 pp. 1-23.
} 
recording the lives of others and how they intersect with her own life, Pilkington is drawn at frequent moments to consider memory as an intellectual faculty, and this objective engagement with memory is almost entirely drawn from Locke. Arguably Locke's interest in subjectivity and identity, the joining up of the dots between past and present selves, as well as his interest in memory as a faculty, held a particularly strong appeal to women who were starting to experiment with life-writing and other autobiographical and self-exploratory modes. Locke defined personal identity as consciousness rather than substance. 'And as far as this consciousness can be extended backwards to any past action or Thought, so far reaches the Identity of that Person; it is the same self now as it was then, and tis by the same self with this present one that now reflects on it, that the Action was done'. ${ }^{45}$ For Locke, consciousness comprises the self, and he emphasizes memory as key - the importance of remembering what one has done as marking identity. Identity reaches forward and backward through time in a continued life

Such concerns shape Pilkington's life-writing. The Memoirs are studded with an unusual awareness of the nature and function of memory. In proto-Proustian mode, she remarks that 'I have observed, that the Scent of a Flower, or the Tune of a Song, always conveys to Remembrance the exact Image of the Place in which they were first noticed' (Memoirs, 1, 282-3). Discussing the relationship between wit, memory and the imagination, she disputes an aphorism in Pope's Essay on Criticism to argue that that memory is a prerequisite for wit. 'I know not how any Person can be witty without a good Memory' (Memoirs, 1, 55). Her own retentive textual memory supplied her with material for wit and play. She drew on between 250-300 quotations from memory for the Memoirs and loved to play games with Swift and in which they matched each other quotation for quotation through the works of Shakespeare and others. Yet Pilkington's obsession with memory was far deeper than textual recall. One day, after reading Locke and speculating 'on that most amazing Faculty of the human Mind, Memory', she writes 'Memory: A Poem'.

In what Recesses of the Brain

Does this amazing Pow'r remain, By which all Knowledge we attain?

\footnotetext{
${ }^{45}$ Locke, Essay Concerning Human Understanding, p. 289.
} 
What art thou, Memory? What Tongue can tell,

What curious Artist trace thy hidden Cell,

Wherein ten thousand different Objects dwell?

Surprising Store-house! in whose narrow Womb

All things, the past, the present, and to come,

Find ample Space, and large, and mighty room.

Where thou art not, the cheerless human Mind

Is one vast Void, all darksome, sad, and blind;

No Trace of anything remains behind.

The sacred Stores of Learning all are thine;

'Tis only thou record'st the faithful Line;

'Tis thou mak'st Humankind almost divine.

(Memoirs, 1. 54-6)

In its scientific approach and intellectual content, 'Memory' is unusual. Pilkington draws here on Locke's transitional treatment of memory, which incorporates earlier ideas of memory as mnemonic system, and a modern, subjective concept of memory that equates memory with identity, individuality and selfhood. Locke in his Essay deploys the traditional spatial metaphors of the classical and Renaissance mnemonic tradition, which views memory, in its ideal form, as a retrieval mechanism for what has been previously stored, memory as a store room, through which the individual moves to retrieve the images placed there. Memory, says Locke, is 'the storehouse of our ideas. For the narrow mind of man, not being capable of having many ideas under view and consideration at once, it was necessary to have a repository to lay up those ideas, which at another time it may have use of. ${ }^{46}$

${ }^{46}$ Essay Concerning Human Understanding, p. 147. 
Pilkington's apostrophe to memory as the 'surprising Storehouse!' echoes Locke's assertion that memory is 'the storehouse of our ideas'. She depicts memory as a cabinet of curiosities made up of 'recesses in the brain', 'a hidden Cell, / Wherein ten thousand different Objects dwell'. It is the repository of the 'Sacred Stores of Learning'. Yet, in an original turn, Pilkington transforms the static 'container' image into an organic, specifically female container: 'In whose narrow womb / All things, the past, the present and to come / Find ample space and large and mighty room'. This container is paradoxically 'narrow' yet also 'mighty', intimate yet expansive, female and gestational. Pilkington wrote the poem when she was pregnant with her daughter Charlotte: maternal imagery here 'approximates the mind's profound generation of mental associations, extends the day's ruminations. Pregnant with expansive reading and literally pregnant with her daughter Charlotte, Pilkington imagines her wit "lay'd up till season due and fit". ${ }^{47}$ Pilkington boldly figures memory as the mother of wit. Whereas earlier male writers such as Rochester and Pope equate the maternal imagery of wombs and procreation with dullness, amnesia and vacuity, Pilkington's gestational metaphor for memory is richly productive. Throughout the Memoirs, we see Pilkington concerned with both the mnemonic aspects of memory - her ability to learn texts off by heart and to recite them, a foundational part of her early girlhood desire to please and be praised, part of the traditional repertoire of female accomplishment - and with memory as individuated, personal history, a capacity for reflection, a linking of past and present selves. Memory is a function of mind, a capacity to recall at will past perceptions and to renew them again.

The legacy of Locke's thought on the women of Dublin still requires further work, including an exploration of the links between Locke, Holland, Dublin and the relationship between medical understanding, cognitive philosophy and educational theory. Yet a close study of the writings of these women, and, in turn, the writings of other contemporary women who produced poetry on a sometimes amateur or domestic basis, not necessarily to get into print, might encourage us to consider the ways in which ordinary women of the 'middling sort' accessed philosophical ideas through their husbands, brothers and sons' education, and how these might have filtered into their works. Not all philosophical debates took place in the public male spaces of school, coffee house and university. The intimacy of Locke's personal

\footnotetext{
${ }^{47}$ See K. I. Berens, 'The Sword Unsheathed: Wit in Laetitia Pilkington's Memoirs', doctoral dissertation, University of California, Berkeley, CA, 1999, pp. 111-12.
} 
correspondence with friends and writers like Molyneux or Cudworth, focusing on maternal relations, sickness and health, care of infants and early education, as well as Locke's personal recollections within his correspondence of the influence of his own father and mother, and his inexhaustible fascination with childhood play and games, might send us back into an examination of the domestic spaces of the period to uncover more about women's engagement with philosophy in the early modern period. 